\title{
FITOKIMIA DAN AKTIVITAS ANTIOKSIDAN EKSTRAK KULIT BATANG Chisocheton sp. (C.DC) Harms (Meliaceae)
}

\author{
Dewa Gede Katja \\ ${ }^{1}$ Jurusan Kimia Fakultas Matematika dan Ilmu Pengetahuan Alam \\ Universitas Sam Ratulangi Manado
}

\begin{abstract}
ABSTRAK
Tujuan penelitian ini untuk mengetahui golongan senyawa metabolit sekunder dan aktivitas antioksidan dari setiap ekstrak kulit batang Chisocheton sp. C.DC Harms (Meliaceae). Hasil ekstraksi $200 \mathrm{~g}$ serbuk kulit batang Chisocheton sp. C.DC Harms (Meliaceae) dengan $\mathrm{n}$-heksana, etil asetat dan metanol masing-masing dengan $2000 \mathrm{~mL}$ berturutturut menghasilkan 7,193 g ekstrak pekat n-heksana, 8,798 g ekstrak pekat etil asetat dan 18,683 g ekstrak pekat metanol. Hasil uji fitokimia menunjukkan adanya golongan senyawa flavonoid, triterpenoid dan tanin. Hasil uji aktivitas antioksidan dengan metode DPPH menunjukkan bahwa ekstrak n-heksana memberikan nilai $\mathrm{IC}_{50}$ sebesar $337,28 \mu \mathrm{g} / \mathrm{mL}$, ekstrak metanol sebesar $216,73 \mu \mathrm{g} / \mathrm{mL}$, dan ekstrak etil asetat sebesar 199,89 $\mu \mathrm{g} / \mathrm{mL}$ yang berarti etil asetat memiliki kemampuan yang paling besar dalam menangkap radikal bebas.
\end{abstract}

Kata kunci: Chisocheton sp. C.DC Harms, flavonoid, triterpenoid, tanin, DPPH, fitokimia

\begin{abstract}
The objective of this study was determine the class of secondary metabolite compounds and antioxidant activity of each stem bark extract of Chisocheton sp. C.DC Harms (Meliaceae). The results of the extraction of $200 \mathrm{~g}$ Chisocheton sp. C.DC Harms (Meliaceae) with n-hexane, ethyl acetate and methanol with $2000 \mathrm{~mL}$ each yielded $7,193 \mathrm{~g}$ of concentrated extract $\mathrm{n}$-hexane, $8,798 \mathrm{~g}$ of concentrated extract of ethyl acetate and 18,683 $\mathrm{g}$ of concentrated methanol extract. Phytochemical test results showed the presence of flavonoid, triterpenoid and tannin compounds. The results of the antioxidant activity test using the DPPH method showed that the n-hexane extract gave an $\mathrm{IC}_{50}$ value of $337,28 \mu \mathrm{g} / \mathrm{mL}$, methanol extract was $216,73 \mu \mathrm{g} / \mathrm{mL}$, and ethyl acetate extract was 199,89 $\mu \mathrm{g} / \mathrm{mL}$ which means that ethyl acetate has the ability to greatest in capturing free radicals.
\end{abstract}

Keywords: Chisocheton sp. C. DC Harms, flavonoid, triterpenoid, tannin, DPPH, phytochemicals

\section{PENDAHULUAN}

Indonesia merupakan negara khatulistiwa yang memiliki iklim tropis dan subtropis, sehingga tumbuh berbagai spesies tumbuhan. Beberapa spesies tumbuhan telah di manfaatkan untuk mengobati berbagai jenis penyakit maupun sebagai sumber berbagai obat baru (Karuppusamy dkk., 2009) salah satunya adalah famili Meliaceae. Tumbuhan ini telah dikenal sebagai tumbuhan penghasil senyawa-senyawa sebagai tumbuhan penghasil senyawa-senyawa yang aktif yang berpotensi sebagai antimalarial, insektisida, antiviral, antioksidan, antikanker, antibakteri, antimikroba, dan antiinflamasi (Heyne, 1987). Chisocheton adalah salah satu genus dari famili Meliaceae, memiliki 50 spesies yang tersebar luas di daerah tropis dan subtropis seperti di Indo-China, Papua Nugini, Cina selatan, Thailand, Malaysia, Nepal, India, Bhutan dan Myanmar (Vossen \& Umali, 2002).

Salah satu penyebab adanya penyakit dalam tubuh manusia adalah radikal bebas (Droge, 2002). Radikal bebas yang terbentuk dalam tubuh akan menghasilkan radikal bebas baru melalui reaksi berantai yang jumlahnya terus bertambah dan menyerang sel-sel tubuh (Khlifi dkk., 2005). Untuk melindungi tubuh dari serangan radikal bebas, diperlukan suatu bahan antioksidan yang bersumber dari bahan alam, sehingga dapat menghambat terjadinya reaksi berantai (Windono dkk., 2001). Antioksidan bertindak sebagai penyumbang radikal bebas (Jadhav dkk., 1996). Sumber-sumber antioksidan dapat berupa antioksidan alami maupun

Korespondensi:

Telepon: +62 813-1492-3544

Email: -

DOI: https://doi.org/10.35799/cp.13.2.2020.31672 
antioksidan sintetik. Contoh antioksidan alami yaitu fenolik, flavonoid, tanin dan vitamin E sedangkan contoh antioksidan sintetik yaitu BHA (butylated hidroxyanisole) dan BHT (butylated hydroxytoluena) (Takashi \& Takayuki, 1997).

Di Pulau Sulawesi, tepatnya Sulawesi Utara Kota Tomohon terdapat salah satu genus Chisocheton dengan spesies Chisocheton sp. (C.DC) Harms. Penelitian ini bertujuan untuk mengetahui kandungan metabolit sekunder meliputi uji warna sebagai uji fitokimia (Harborne, 1987) dan aktivitas antioksidan dari ekstrak kulit batang Chisocheton sp. (C.DC) Harms.

\section{BAHAN DAN METODE}

\section{Bahan dan alat}

Bahan yang digunakan yaitu serbuk dari kulit batang tumbuhan Chisocheton sp. (C.DC) Harms, metanol, heksana, etil asetat, klorofom, asam sulfat, $\mathrm{FeCl}_{3} 1 \%$, asam asetat anhidrat, $\mathrm{NaCl}$, amonia, aquades, etanol, asam klorida, serbuk magnesium, pereaksi Mayer, pereaksi Dragendorff, pereaksi Wagner, reagen Folin-Ciocalteu 50\%, natrium karbonat dan 1,1difenil-2-pikrilhidrazil (DPPH). Alat yang digunakan yaitu gelas kimia, gelas ukur, botol vial besar, labu ukur, spatula, corong kaca, rotary evaporator, oven, timbangan digital, rak tabung reaksi, pipet tetes, mikropipet, kertas saring, cawan petri, pisau, blender, vortex, ayakan 65 mesh, spektrofotometer UV-Vis.

\section{Preparasi sampel}

Sampel kulit batang Chisocheton sp. (C.DC) Harms di ambil di gunung Soputan Tomohon. Sampel kulit batang yang diperoleh terlebih dahulu dibersihkan selanjutnya dikering-anginkan selama 7 hari, kemudian dipotong kecil-kecil lalu ditumbuk kemudian diblender dan diayak dengan ayakan 65 mesh hingga diperoleh serbuk.

\section{Ekstraksi maserasi}

Sebanyak $200 \mathrm{~g}$ serbuk kulit batang Chisocheton sp. (C.DC) Harms diekstraksi dengan cara maserasi selama $5 \times 24$ jam menggunakan pelarut $n$-heksana sebanyak $2000 \mathrm{~mL}$, selanjutnya disaring hingga diperoleh filtrat. Filtrat yang diperoleh kemudian dievaporasi menggunakan rotary evaporator. Kemudian dikeringkan dalam oven pada suhu $40^{\circ} \mathrm{C}$ hingga diperoleh ekstrak pekat. Diulangi kembali perlakuan yang sama untuk pelarut etil asetat dan metanol.

\section{Skrinning fitokimia}

Ekstrak kental kulit batang dari beberapa pelarut di analisis dengan dilakukan uji kandungan alkoloid, saponin, flavonoid, steroid, triterpenoid, fenolik dengan langkah sebagai berikut:

\section{Pembuatan larutan uji fitokimia}

Pembuatan larutan uji untuk skrinning fitokimia dilakukan dengan melarutkan $0,05 \mathrm{~g}$ ekstrak kental $n$-heksana dalam $50 \mathrm{~mL}$ metanol kemudian di vortex sampai larutan tercampur. Diulangi perlakuan yang sama untuk ekstrak kental etil asetat dan metanol.

\section{Identifikasi kandungan alkaloid}

Sebanyak $2 \mathrm{ml}$ larutan uji dari pelarut heksan, dimasukkan dalam tabung reaksi dan ditambahkan 5 tetes amonia pekat. Setelah itu, disaring kemudian ditambah $2 \mathrm{ml}$ asam sulfat $2 \mathrm{~N}$ dan dikocok hingga memberi lapisan atas dan bawah. Lapisan atas dibagi menjadi 3 bagian, pada tabung pertama ditambahkan 1 tetes mayer, adanya alkaloid ditandai dengan terbentuknya endapan. Pada tabung kedua ditambah 1 tetes pereaksi Dragendorf dan terbentuknya endapan menandakan adanya alkaloid. Tabung ketiga ditambah 1 tetes pereaksi Wagner dan terbentuknya endapan coklat menandakan adanya alkaloid. Diulangi perlakuan yang sama untuk larutan uji etil asetat dan metanol.

\section{Uji kandungan steroid dan triterpenoid}

Sebanyak $2 \mathrm{~mL}$ larutan uji dari masingmasing ekstrak dimasukkan ke dalam tabung reaksi. Kemudian masing-masing ditambah dengan asam asetat anhidrat 1 tetes dan asam sulfat pekat 2 tetes. Jika terbentuk warna biru atau hijau menandakan adanya steroid. Jika terbantuk warna ungu atau jingga menandakan adanya triterpenoid.

\section{Uji kandungan flavonoid}

Sebanyak $2 \mathrm{ml}$ larutan uji dari masingmasing ekstrak dimasukkan dalam tabung reaksi. Kemudian ditambah dengan 5 tetes etanol, lalu dikocok sampai homogen. Setelah itu ditambah dengan serbuk $\mathrm{Mg}$ 0,2 gr dan 5 tetes $\mathrm{HCl}$ pekat. Jika menghasilkan warna kuning, orange, dan merah menandakan adanya flavonoid. 


\section{Uji kandungan saponin}

Sebanyak $2 \mathrm{ml}$ larutan uji dari masingmasing ekstrak dimasukkan dalam tabung reaksi. Kemudian ditambah $2 \mathrm{ml}$ aquades, lalu dikocok sampai homogen. Setelah itu, dipanaskan selama 23 menit. Dinginkan, setelah dingin kocok dengan kuat. Adanya busa yang stabil selama 30 detik menunjukkan sampel mengandung saponin.

\section{Uji kandungan tanin}

Sebanyak $2 \mathrm{ml}$ larutan uji dari masingmasing ekstrak dimasukkan dalam tabung reaksi. Kemudian masing-masing tabung reaksi ditambahkan dengan $\mathrm{FeCl}_{3}$ 1\% 2-3 tetes. Adanya tanin ditandai dengan terbentuknya warna biru tua atau hitam kehijauan.

\section{Penentuan kandungan total fenolik}

Kandungan total fenolik kulit batang Chisocheton sp. C.DC Harms ditentukan dengan metode Folin Ciocalteu. Sebanyak 0,1 mL larutan ekstrak ditambahkan $0,1 \mathrm{~mL}$ reagen Folin Ciocalteu $50 \%$. Kemudian divortex, lalu ditambahkan $2 \mathrm{~mL}$ larutan natrium karbonat $\left(\mathrm{Na}_{2} \mathrm{CO}_{3}\right) \quad 2 \%$. Selanjutnya, campuran diinkubasi dalam ruang gelap selama 30 menit. Diukur absorbansi pada panjang gelombang $750 \mathrm{~nm}$ menggunakan spektrofotometer UV-Vis. Kandungan total fenolik dinyatakan sebagai $\mathrm{mg}$ ekuivalen asam galat / $\mathrm{g}$ ekstrak.

\section{Pengujian aktivitas antioksidan}

Pengujian aktivitas antioksidan ekstrak kulit batang Chisocheton sp. C.DC Harms ditentukan dengan metode Muaja dkk. (2017). Larutan ekstrak dan DPPH dibuat terlebih dahulu. Ekstrak dilarutkan dalam metanol dan larutan DPPH dibuat dengan konsentrasi $0,4 \mathrm{mM}$. Larutan sampel yang telah dibuat diencerkan dengan berbagai konsentrasi dengan total volume $1 \mathrm{~mL}$ dan dimasukkan ke dalam tabung reaksi sebagai larutan uji dan dibuat juga untuk blanko. Selanjutnya ke dalam tabung reaksi larutan uji ditambahkan 0,2 $\mathrm{mL}$ larutan DPPH dan diinkubasi selama 30 menit dalam kondisi gelap. Selama 30 menit, blanko dan larutan uji diukur absorbansinya dengan menggunakan spektrofotometer UV-Vis pada panjang gelombang $517 \mathrm{~nm}$, nilai absorbansi dari setiap variasi konsentrasi dcatat dan dihitung \% scavenging dan nilai $\mathrm{IC}_{50}$ pengujian dilakukan sebanyak dua kali. Perhitungan nilai $\mathrm{IC}_{50}$ dinyatakan dengan persamaan regresi linear dan perhitungan $\%$ scavenging dinyatakan dengan persamaan sebagai berikut :

$$
\% \text { scavenging }=\left(\frac{A_{\text {kontrol }}-A_{\text {sampel }}}{A_{\text {kontrol }}}\right) \times 100 \%
$$

Keterangan: $\mathrm{A}_{\text {kontrol }}=$ Absorbansi DPPH, $\mathrm{A}_{\text {sampel }}=$ Absorbansi DPPH + sampel

\section{HASIL DAN PEMBAHASAN}

\section{Ekstraksi}

Kulit batang Chisocheton sp. (C.DC) Harms dihaluskan sampai berbentuk serbuk dengan menggunakan blender, yang bertujuan untuk memperkecil ukuran sampel. Semakin kecil ukuran sampel, semakin besar luas permukaan sehingga dapat mempengaruhi interaksi sampel dengan pelarut maka proses ekstraksi dengan metode maserasi berlangsung optimal dan menghasilkan ekstrak yang maksimal. Ditimbang 200 gram serbuk kering kulit batang Chisocheton $s p$. (C.DC) Harms di maserasi berturut-turut dengan $n$-hexan, etil asetat dan metanol. Diperoleh ekstrak pekat $n$ heksane 7,193 g, ekstrak etil asetat 8,798 g dan ekstrak metanol 18,683 g. 


\section{Identifikasi fitokimia}

Hasil identifikasi fitokimia kulit batang Chisocheton sp. C.DC Harms dilihat pada tabel 1.
Hasil skrining fitokimia pada Tabel 1, ekstrak metanol dan etil asetat menunjukkan adanya senyawa golongan flavonoid, tanin dan triterpenoid.

Tabel 1. Identifikasi skrinning fitokimia

\begin{tabular}{lllc}
\hline \multicolumn{1}{c}{ Senyawa } & \multicolumn{1}{c}{ Ekstrak } & \multicolumn{1}{c}{ Perubahan Warna } & Keterangan \\
\hline \multirow{2}{*}{ Alkaloid } & Metanol & Orange kecokelatan menjadi orange & - \\
& Etil asetat & Orange menjadi kuning & - \\
& $n$-heksan & Kuning pudar menjadi kuning & - \\
& Metanol & Orange kecokelatan menjadi orange kemerahan & + \\
Flavonoid & Etil asetat & Cokelat menjadi orange kemerahan & + \\
& $n$-heksana & Kuning pudar menjadi bening & + \\
& Metanol & Cokelat menjadi biru tua & + \\
Tanin & Etil asetat & Cokelat menjadi biru tua & + \\
& $n$-heksana & Kuning pudar menjadi kuning & + \\
& Metanol & Orange kecokelatan menjadi jingga & + \\
Triterpenoid & Etil asetat & Cokelat menjadi jingga & - \\
& $n$-heksana & Kuning pudar menjadi bening & - \\
& Metanol & Orange kecokelatan menjadi orange & - \\
\hline Saponin & Etil asetat & Cokelat menajdi orange & - \\
& $n$-heksana & Kuning pudar menjadi bening & \\
\hline
\end{tabular}

\section{Kandungan total fenolik}

Uji kandungan total fenolik dengan metode Folin-Ciocalteu bertujuan untuk mengetahui jumlah fenol yang terkandung dalam ekstrak $n$-heksana, etil asetat dan metanol kulit batang Chisocheton $s p$. C.DC Harms. Metode ini didasarkan pada kemampuan ekstrak untuk mereduksi reagen Folin-
Ciocalteu (kuning) yang mengandung senyawa fosfomolibdat dan asam fosfotungstat menghasilkan senyawa kompleks molybdenumfungstat berwarna biru (Julkunen-Tiito, 1985). Semakin biru intensitas warna larutan menunjukan kandungan total fenol dalam sampel semakin besar (Larson, 1988). Hasil kandungan total fenolik dapat dilihat pada tabel 2. 
Tabel 2. Kandungan total fenolik ekstrak metanol: etil asetat dan $n$-heksana kulit batang Chisocheton sp. C.DC Harms

\begin{tabular}{lc}
\hline Ekstrak & $\begin{array}{c}\text { Kandungan total fenolik } \\
(\mu \mathrm{g} / \mathrm{mL})\end{array}$ \\
\hline Metanol & $91,54 \pm 0,45^{\mathrm{a}}$ \\
Etil asetat & $94,79 \pm 0,36^{\mathrm{b}}$ \\
$n$-Heksana & $23,68 \pm 0,12^{\mathrm{c}}$ \\
\hline
\end{tabular}

Keterangan: Huruf yang berbeda di belakang angka menunjukkan perbedaan yang signifikan

Berdasarkan Tabel 2, menunjukkan bahwa kandungan total fenolik terbesar ada pada ekstrak etil asetat yakni 94,79\%, ekstrak metanol 91,54\%, dan ekstrak $n$-heksana 23,68\%. Hal ini dikarenakan pelarut etil asetat dapat melarutkan senyawa fenolik yang lebih banyak sehingga menunjukkan sebagian besar senyawa fenølik yang terdapat pada kulit batang Chisocheton sp. C.DC Harms merupakan senyawa yang bersifat semipolar. Rohman dkk. (2006) melaporkan bahwa pelarut etil asetat sangat cocok untuk mengekstraksi senyawa fenolik.

\section{Aktivitas antioksidan}

Pengujian aktivitas antioksidan menggunakan metode Muaja dkk. (2017). Hasil uji aktivitas antioksidan terdapat pada Gambar 2.

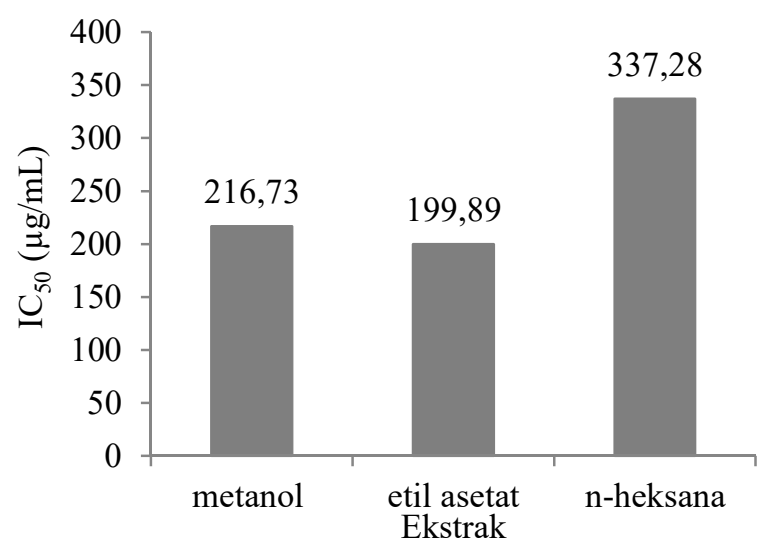

Gambar 2. Aktivitas antioksidan ekstrak metanol, etil asetat dan n-heksana dari kulit batang

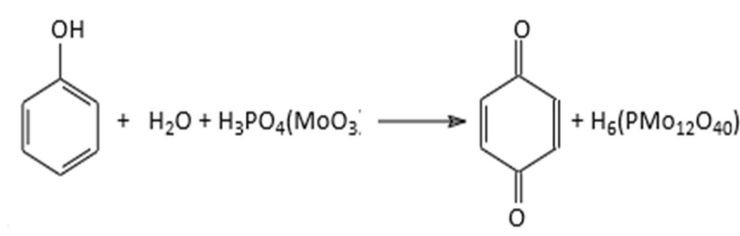

Gambar 1. Reaksi senyawa fenol dengan reagen Folin-Ciocalteu (Hardiana dkk., 2012)

Berdasarkan Gambar 2 menunjukkan hasil ekstrak etil asetat memiliki nilai $\mathrm{IC}_{50}$ yang paling rendah yaitu $199,89 \mu \mathrm{g} / \mathrm{mL}$, ekstrak metanol 216,73 $\mu \mathrm{g} / \mathrm{ml}$, dan ekstrak $n$-heksana 337,28 $\mu \mathrm{g} / \mathrm{ml}$. semakin rendah $\mathrm{IC}_{50}$ maka semakin besar aktivitas antioksidannya. Penentuan nilai aktivitas antioksidan menggunakan metode DPPH. Metode ini merupakan metode yang sederhana, mudah, cepat dan tidak membutuhkan banyak reagen seperti halnya metode lain. Metode ini menggunakan prinsip spektrofotometri. Senyawa DPPH dalam metanol berwarna ungu tua terdeteksi pada panjang gelombang $517 \mathrm{~nm}$. Parameter untuk menginterpretasikan hasil pengujian DPPH adalah dengan nilai $\mathrm{IC}_{50}$ (Inhibitor Concentration). $\mathrm{IC}_{50}$ merupakan konsentrasi larutan substrat atau sampel yang mampu mereduksi aktivitas DPPH sebesar $50 \%$. Semakin kecil nilai $\mathrm{IC}_{50}$ berarti semakin tinggi aktivitas antioksidan. Hal ini menunjukan bahwa esktrak etil asetat mempunyai aktivitas antioksidan yang kuat karena mempunyai nilai $\mathrm{IC}_{50}$ kurang dari $200 \mu \mathrm{g} / \mathrm{ml}$ (Blouis, 1958). Hasil reaksi antara penangkap radikal bebass DPPH dengan senyawa antioksidan dapat diketahui melalui perubahan warna dari ungu pekat menjadi kuning akibat terjadi resonansi struktur penangkap radikal bebas DPPH.

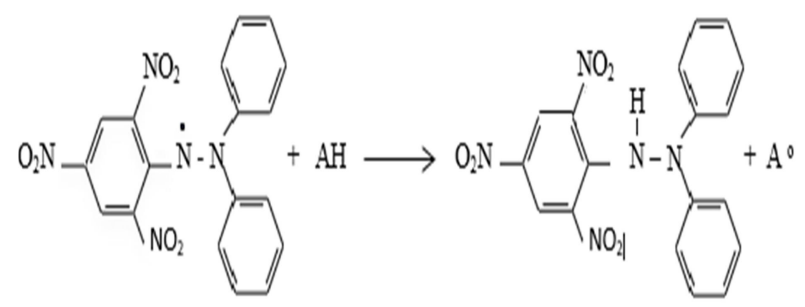

Gambar 3. Reaksi antara penangkal radikal (AH) dengan radikal bebas DPPH (Landeng dkk., 2017) 


\section{KESIMPULAN}

Uji fitokimia ekstrak kulit batang Chisocheton sp. (C.DC) Harms, menunjukkan adanya senyawa Flavonoid, triterpenoid dan tanin dan memiliki aktivitas antioksidan. Ekstrak etil asetat memiliki aktivitas antioksidan yang tinggi dibandingkan dengan ekstrak metanol dan ekstrak $n$-heksana.

\section{DAFTAR PUSTAKA}

Blouis, M.S. 1958. Antioxidant determinations by the use of a stable free radical. Nature. 181(4617), 1199-1200.

Droge, W. 2002. Free radicals in the physiological control of cell function. Physical Review. 82(1), 47-95.

Hardiana, R. \& Rudiyansyah, T.A. 2012. Aktivitas antioksidan senyawa golongan fenol dari beberapa jenis tumbuhan Famili Malvaceae. Jurnal Kimia Khatulistiwa. 1(1), 8-13.

Heyne, K. 1987. Tumbuhan Berguna Indonesia. Badan Litbang Departemen Kehutanan. Jakarta.

Inada, A., Sukemawa, M., Murata, H., Nakanishi, T., Tokuda, H., Nishino, H., Iwashima, Darnaedi, D.J. \& Murata, J. 1993. Phytochemical studies on maleaceous plant. Part VIII. Structures and inhibitory effects on epstein-barr virus activation of triterpenoida from leaves of chisocheton macrophyllus king. Chem. Pharm. Bull. 41(3), 617-619.

Jadhav, S.J., Nimbalkar, S.S., Kulkarni, A.D. \& Madhavi, D.L. 1996. Lipid Oxidation in Biological and Food Systems. Dalam D. L. Madhavi, S.S. Deshpandeand D.K Salunkhe (eds). Food Antioxidants Technological, Toxicological, and Health, Drespectives. Marcel Dekker, Inc, New York.

Karuppusamy, S., Kiranmai, C., Aruna, V. \& Pullaiah, T. 2009. In vitro conservation of Ceropegia intermedia-an endemic plant of south India. African Journal of Biotechnology. 8(17), 4052-4057.

Khlifi, S., Hachimi, Y., Khalil, A., Essafi, N. \& Abbouyi, A. 2005. In vitro antioxidant effect of Globularia alypum L. hydromethanolic extract. Indian Journal of Pharmacology. 37(4), 227-231.

Landeng, P.J., Suryanto, E. \& Momuat, L.I. 2017. Komposisi proksimat dan potensi antioksidan dari biji jagung manado kuning (Zea mays L.). Chemistry Progress. 10(1), 36-44.

Larson, R.A. 1988. The antioxidants of hinghest plants. Phytochemistry. 27(4), 969-977.

Molyneux, P. 2004. The use of stable free radical diphenylpicrylhydrazyl (DPPH) for estimating antioxidant activity. Journal of Materials Science \& Technology. 26(2), 211- 219.

Muaja, M.G.D., Runtuwene, M.R.J. \& Kamu, V.S. 2017. Aktivitas antioksidan ekstrak metanol dari daun soyogik (Saurauia bracteosa DC). Jurnal Ilmiah Sains. 17(1), 68-72.

Rohman, A., Riyanto, S. \& Utari, D. 2006. Aktivitas antioksidan, kandungan fenolik total dan kandungan flavonoid total ekstrak etil asetat buah mengkudu serta fraksi-fraksinya. Majalah Farmasi Indonesia. 17(3), 136-142.

Takashi, M. \& Takayuki, S. 1997. Antioxidative activities of natural compounds found in plants. Journal of Agricultural and Food Chemistry. 45(5), 1819-1822.

Vossen, V.D.H.A.M. \& Umali, B.E. 2002. Plant resources of south-east Asia no. 14 vegetable oils and fats. Proses Foundation. Bogor, Indonesia.

Windono, T., Soediman, S., Yudawati, U., Ermawati, E., Srielita \& Erowati, T.I. 2001. Uji perendam radikal bebas terhadap 1,1- diphenyl-2 picrylhydrazil (DPPH) dari ekstrak kulit buah dan biji anggur (Vitis vinitera L.) Probolinggo Biru dan Bali. Artocarpus. 1(1), 34-43. 